University of San Diego

Digital USD

3-23-2016

\title{
Like Snow to the Eskimos and Trump to the Republican Party: The Ali's Many Words for, and Shifting Pronouncements About, "Affirmative Consent"
}

Kevin Cole

University of San Diego School of Law

Follow this and additional works at: https://digital.sandiego.edu/law_fac_works

Part of the Criminal Law Commons, and the Criminal Procedure Commons

\section{Digital USD Citation}

Cole, Kevin, "Like Snow to the Eskimos and Trump to the Republican Party: The Ali's Many Words for, and Shifting Pronouncements About, "Affirmative Consent"'" (2016). Faculty Scholarship. 6.

https://digital.sandiego.edu/law_fac_works/6 accepted for inclusion in Faculty Scholarship by an authorized administrator of Digital USD. For more information, please contact digital@sandiego.edu. 
LIKE SNOW TO THE ESKIMOS AND TRUMP TO THE REPUBLICAN PARTY: THE ALI'S MANY WORDS FOR, AND SHIFTING PRONOUNCEMENTS ABOUT, "AFFIRMATIVE CONSENT"

\section{Kevin Cole ${ }^{1}$}

Because we generally see little advantage in distinguishing among various kinds of snow, we are amused by the idea that the Eskimo languages have a great number of words for it - even if that idea is false. We can appreciate however, that "affirmative consent" can take many forms. Objections to and support for affirmative-consent standards will vary depending not only on the reader's perspective but also on how the affirmativeconsent standard is implemented.

The drafters of the American Law Institute's draft sexual assault provisions have defined "consent" in a striking number of ways over the past several months. Commentary accompanying those provisions has also shifted quickly over this period. The earlier commentary clearly classified the proposal as an affirmative-consent standard, even though it rejected the requirement advocated by some that sexual penetration be preceded by verbal permission. More recent drafts, on the other hand, claim to reject an affirmative-consent approach in favor of a "contextual-consent" model.

In a previous piece, ${ }^{2}$ I traced the recent "consent" definitions through Council Draft No. $3^{3}$ and argued that the alleged shift from affirmative to contextual consent changed little of substance and did not respond to the most serious problems with the earlier drafts, which I had previously discussed at length. ${ }^{4}$ This short follow up addresses the changes between Council Draft No. 3 and the newest draft, Preliminary Draft No. 6. In some respects, the current draft reverses course on concessions previously made to critics. In others, the current draft makes changes that appear to respond to concerns but couple them with other changes that undermine the reform. And on the central issue of the mens rea required for conviction, the draft continues an approach that likely would be implemented so as to impose liability for those guilty of mere tort negligence in failing to recognize the social harm they were risking - that their

\footnotetext{
1 (c) 2016, Kevin Cole. Professor, University of San Diego, School of Law.

${ }^{2}$ Kevin Cole, Backpedalling in Place: The ALI's Move from "Affirmative" to "Contextual" Consent (available at http://papers.ssrn.com/sol3/papers.cfm?abstract_id=2714057).

${ }^{3}$ Model Penal Code: Sexual Assault and Related Offenses (Council Draft No. 3, Dec. 15, 2015) [hereinafter DEC. DRAFT].

${ }^{4}$ Kevin Cole, Better Sex Through Criminal Law: Proxy Crimes, Covert Negligence, and Other Difficulties of "Affirmative Consent" in the ALI's Draft Sexual Assault Provisions, _ SAN DIEGO L. REV. __ (forthcoming 2016) (Oct. 2015 draft available at http://papers.ssrn.com/sol3/papers.cfm?abstract_id=2670419).

${ }^{5}$ Model Penal Code: Sexual Assault and Related Offenses (Preliminary Draft No. 6, Mar. 2, 20165) [hereinafter CURRENT DRAFT].
} 
partners were not willing to engage in the sex act in question. ${ }^{6}$ This was the most troubling feature of the project's early affirmative-consent proposals, and it persists, regardless of the word used to describe it.

\section{MENS REA}

The current draft changes the definition of consent but is still most likely to be interpreted contrary to the Model Penal Code's usual approach requiring subjective culpability regarding the social harm at issue-the partner's unwillingness. Previously, the draft forbade penetration in the absence of "positive agreement," and later "agreement." Now, the draft forbids penetration without "behavior, including words, conduct, acts, and omissions, that communicates willingness to engage in a specific act of sexual penetration." Like earlier versions, the current consent definition articulates an objective conception of consent - consent is not the partner's mental state, but rather certain manifestations of the partner's mental state, the "behavior ... that communicates willingness."

As argued previously, ${ }^{7}$ these kinds of objective standards are especially likely to be viewed as questions of law not subject to the mens rea language in a statute. ${ }^{8}$ Presumably the jury will determine which historical facts the actor nonrecklessly believed. Then the jury will determine the normative question of whether those historical facts suffice to establish "behavior . . . that communicates willingness." That normative question is one regarding which the actor's mens rea is not clearly required, and it is the kind of question that is often regarded as a legal question to which mens rea requirements do not apply. In essence, the actor's subjective mental state is likely to be relevant regarding the historical facts regarding consent, but not whether those facts would suffice to meet the normative standard of consent. ${ }^{9}$

\footnotetext{
${ }^{6}$ For elaboration of the idea that the social harm in sexual assault turns on the subjective mental state of the partner, see Cole, supra note 2, at 6.

${ }^{7}$ See id. at 8.

8 The switch from "positive agreement" and "agreement" to the current "behavior . . . that communicates willingness" eliminates the argument that "agreement," because of its use in contracts, implies a reasonableness standard. But the current standard still appears to be an objective standard, and the commentary to the current draft reinforces that impression.

${ }^{9}$ For a recent example of this approach, see Elonis v. United States, 135 S. Ct. 2001 (2015), involving the question of whether defendant was guilty of making a prohibited "threat." While the majority rejected the view that the requirement was met when a person intentionally uttered words that a reasonable person would have taken to be a threat, Justice Thomas's dissenting opinion suggests a different analysis. Id. at 2019 (Thomas, J., dissenting) (citations omitted) ("Under this 'conventional mens rea element,' 'the defendant [must] know the facts that make his conduct illegal,' but he need not know that those facts make his conduct illegal. It has long been settled that 'the knowledge requisite to knowing violation of a statute is factual knowledge as distinguished from knowledge of the law."'); $i d$. at 2021 ("Knowing that the communication contains a 'threat' - a serious expression of an intention to engage in unlawful physical violence - does not, however, require knowing that a jury will conclude that the communication contains a threat as a matter of law.").
} 
The current draft's many illustrations that require the actor to be at least reckless regarding consent do not conflict with this reading, since in each one the mens rea requirement could be applied to the historical component of the consent requirement rather than to normative component. Indeed, given that the draft has now specified the mental state its proxy rule seeks to serve (willingness), the illustrations would most likely speak in terms of willingness (instead of consent) when they discuss mens rea if they were indeed intended to signal that the actor must be subjectively culpable about what the partner's behavior means. That is certainly how the commentary spoke several drafts ago when it tried to make that point in defense of its proposal to apply the affirmative-consent model to all sexual conduct. ${ }^{10}$ Nothing in the current illustrations speaks to mens rea in this way. In fact, Illustration 2 in the current draft speaks in negligence language, though in a somewhat confusing way. ${ }^{11}$

\section{THE UNDERLYING SOCIAL HARM}

The draft's shift from "positive agreement" and "agreement" to "behavior communicating willingness" is an advance in that it removes one element of ambiguity from those earlier formulations - the draft's view of the partner's mental state that describes the social harm sought to be avoided with the draft's proxy rules. We now know that the mental state is unwillingness, rather than unwelcomeness, lack of enthusiasm, and the like.

But we may know less than we think. The Reporters' Memorandum proclaimed that Council Draft No. 3 "eliminates language requiring the consent to be 'positive,' 'freely given,' and 'absent until . . . communicated."'12 But in the current draft, the "freely given" requirement reappears in slightly different garb. The draft requires that "All the circumstances must be considered in determining whether a person has given consent, including any physical or verbal resistance and any circumstances preventing or constraining resistance." 13

This open-ended language has the potential to undo any increased clarity the draft may have promised. That is because a partner's willingness is usually influenced by many factors, some of which we will deem to vitiate consent. For example, one might say that a person is willing to have sex when threatened with death as an alternative, in that the person prefers sex to death. Obviously, if the consent standard were our only weapon, we would need to

\footnotetext{
${ }^{10}$ See Model Penal Code: Sexual Assault and Related Offenses at 127 (Discussion Draft No. 2, Apr. 28, 2015) (emphasis added) ("If the actor honestly and sincerely believes the date went well and a sexual overture is welcomed, there should not be liability even if the other person in fact found the date insufferable, and yet continued to be politely accommodating. The Code requires that the actor be at least recklessly aware of the absence of consent - in other words, aware of a risk that the other person does not in fact welcome the behavior.").

11 See CURRENT Draft, supra note 5, at 6 ("And even if B were not thought to have consented, A could reasonably believe that she had; he was not reckless as to whether she had consented.").

12 DEC. DRAFT, supra note 3, at xi.

${ }^{13}$ Current DraFT, supra note 5, § 213.0(3)(b) (emphasis added).
} 
have a provision indicating that a threat of death vitiates consent. Although consent is not the draft's only weapon, the draft already has a provision specifying certain specific conditions as vitiating consent. ${ }^{14}$

The open-ended language about circumstances constraining resistance could be used to add to this list in unpredictable ways. For example, if a partner agrees to sex because of an actor's cajolery, is the partner's continuing resistance been constrained by that cajolery? To abstract from a recently publicized case, if a partner agreed to have sex rather than walking across a cold campus to her own dorm room, knowing that the actor would not let her stay unless they had sex, is the partner's continued resistance constrained by the choice she faced?

If "circumstances . . . constraining resistance" is not given a narrow interpretation, the apparent gain in clarity achieved by the reformulated consent standard will quickly take on the same murky quality that the drafters claimed to reject in Council Draft No. 3.

\section{ObJective CONSENT Standards AND THE Baseline QUESTION}

Council Draft No. 3 stated, "Although a subjective definition of 'consent' has appeal, only a conduct-based conception of consent is workable." 15 Apparently, the drafters thereafter became aware that the Restatement of Torts has for many years defined "consent" in subjective terms, for the current draft states, "Although a subjective definition of consent has appeal, only a behavior-based concept is workable in the criminal law."16

The draft nowhere explains this position. But one obvious difference is that in the criminal law, the actor needs to be proven guilty beyond a reasonable doubt. And so one might infer that the reason the drafters believe a subjective standard would be unworkable in the criminal law is that convictions would be too hard to obtain under that standard.

The same could be said, of course, about the other crimes covered by the Model Penal Code, for which the Code typically required subjective awareness of the risk of social harm, or at least gross negligence regarding that risk. It is doubtless true that the problems of proving guilt of sexual assault are typically greater than the problems of proof surrounding many crimes. It is also true, however, that in sexual assault cases, proving innocence is harder too.

Many jurisdictions do apply objective consent standards in sexual assault cases. A question remains as to what baseline the ALI should consult in

${ }^{14} I d . \S 213.0(3)(\mathrm{d})$.

${ }^{15}$ DEC. DRAFT, supra note 3 , at 2.

${ }^{16}$ CURRENT DRAFT, supra note 5, at 3 (emphasis added). 
assessing the draft. Should it look to how the draft fits with the principles of the Model Penal Code, or instead look to the state of the law across the country? Some skepticism is justified regarding objective consent standards in the states. They developed against a backdrop of resistance requirements that largely eliminated the need to think about fairness to the defendant in the consent standard. Indeed, many jurisdictions made consent a strict liability element. More generally, politicians rarely lose votes by being tough on crime. In California, for example, simple negligence in causing death by automobile is a crime. That the Model Penal Code's approach has not gained uniform acceptance is insufficient reason to abandon it now. Indeed, if anything, developments since the promulgation of the Model Penal Code suggest that now more than ever, a model of fair criminal law is a useful counterweight to the pressures that push legislators toward harsh criminal responses to social problems.

\section{REFORM THROUGH FATIGUE}

ALI critics of the sexual assault proposal could not be faulted for feeling as if they are in a game of Whack-a-Mole designed to end in rotatorcuff surgery. High penalties for sex in the absence of affirmative consent were replaced with misdemeanor penalties, but have now risen to the felony level again. Early versions of the project included a provision that would criminalize a wide range of inducements that would vitiate apparent consent, a provision eliminated only to be replaced with an open-ended requirement that consent be "freely given," which has now been replaced with a requirement of attention to circumstances constraining resistance. Critics concerned that commentary favorable to defendants did not match the statutory text saw the text amended to include some of those ideas, only to see that text disappear in the most recent draft. ${ }^{17}$ Bold proclamations of a shift from "affirmative" to "contextual" consent end up, on examination, to have changed very little. ${ }^{18}$

Public-choice theory teaches that those most interested tend to win in the legislative process. The ALI is not immune from this dynamic. Specialists in sexual assault law have greater incentives to see their ideas embraced than generalists have to oppose them. Eventually, even dedicated and thoughtful generalists will be tempted to point to the progress they have made in reining in the specialists and to declare victory. The losers in the process await identification, through the criminal process.

17 Compare, e.g., DEC. DRAFT, supra note 3, § 213.0(3)(b) ("Neither verbal nor physical resistance is required to establish the absence of consent, but lack of physical or verbal resistance may be considered, together with all other circumstances, in determining whether a person has given consent."), with CURRENT DRAFT, supra note 5, §213.0(3)(b) ("Neither verbal nor physical resistance is required to establish the absence of consent.").

${ }^{18}$ See Cole, supra note 2. 